\title{
Effects of phenolic compounds in propolis on digestive and ruminal parameters in dairy cows
}

\author{
Sílvia Cristina de Aguiar ${ }^{1}$, Eduardo Marostegan de Paula ${ }^{1}$, Emerson Henri Yoshimura ${ }^{1}$, Wallacy \\ Barbacena Rosa dos Santos ${ }^{1}$, Erica Machado', Maribel Velandia Valero ${ }^{1}$, Geraldo Tadeu \\ dos Santos ${ }^{1}$, Lucia Maria Zeoula ${ }^{1}$
}

\footnotetext{
${ }^{1}$ Universidade Estadual de Maringá, Maringá, PR, Brasil.
}

\begin{abstract}
Four rumen-cannulated primiparous lactating cows were studied in a $4 \times 4$ Latin square design experiment to evaluate the effects of propolis-based products (PBP) with different concentrations of propolis and alcohol levels on total digestibility, (TD), ruminal digestibility (RD), intestinal digestibility (ID), $\mathrm{pH}$, ruminal ammonia-nitrogen production $\left(\mathrm{NH}_{3}-\mathrm{N}\right.$ ), rumen microbial synthesis, and blood parameters. The feed consisted of $591.9 \mathrm{~g} / \mathrm{kg}$ corn silage and $408.1 \mathrm{~g} / \mathrm{kg}$ concentrate (dry matter $[\mathrm{DM}]$ basis), and treatments differed with regard to the inclusion (via ruminal cannula) or exclusion of PBP as follows: control (without the PBP), PBP B1 (3.81 mg of phenolic compounds/kg of ingested DM), PBP C1 (3.27 mg of phenolic compounds $/ \mathrm{kg}$ of ingested DM), and PBP C3 (1.93 mg of phenolic compounds $/ \mathrm{kg}$ of ingested DM). Inclusion of PBP reduced the $\mathrm{RD}$ of dietary crude protein $(\mathrm{CP})$. Treatment $\mathrm{PBP} \mathrm{C} 1$ reduced ruminal $\mathrm{NH}_{3}-\mathrm{N}$ production, while PBP B1 increased the ID of $\mathrm{CP}$ relative to that in the control. These findings indicate that propolis had a positive effect on rumen nitrogen metabolism. Rumen $\mathrm{pH}$, efficiency of microbial protein synthesis, and blood parameters were not affected by addition of PBP, but there were significant effects on the other parameters when the treatments containing propolis were contrasted. Higher TD of DM (0.717 vs. 0.685$), \mathrm{OM}(0.737$ vs. 0.703$)$, and $\mathrm{CP}(0.760$ vs. 0.739$)$, as well as higher NDF (0.622 vs. 0.558$)$ and TDN (0.747 vs. 0.712$)$ were observed when comparing PBP C1 with C3. Inclusion of propolis in diets for dairy cows have positive effects on protein metabolism in the rumen. Variation in the amounts of phenolic compounds in the different PBP may explain the diverse effects on the digestive parameters evaluated.
\end{abstract}

Key Words: additive, ammonia nitrogen, flavonoids, phenolic acids, ruminants

\section{Introduction}

The commonly used additives in ruminant nutrition have an important role as modulators of the end products of rumen fermentation; however, the use of antibiotics in animal feeds is facing decreased social acceptance, and their use has been forbidden in the European Union since January 2006 (Calsamiglia et al., 2007). For this reason, there is substantial interest in evaluating the potential of natural antimicrobials such as plant extracts to modify rumen microbial fermentation (Busquet et al., 2006). The plants of interest produce a diverse array of secondary compounds, which have benefits in ruminant production (Wallace, 2004). These compounds, including phenylpropanoids and flavonoids, are known to have an impact on rumen microbial metabolism by inducing changes in the fermentation conditions $(\mathrm{pH}$, propionate proportion, and protein degradation) (Broudiscou et al., 2002; Balcells et al., 2012).

\footnotetext{
Received August 7, 2013 and accepted January 23, 2014.

Corresponding author: scdeaguiar@ig.com.br

http://dx.doi.org/10.1590/S1516-35982014000400006
}

Copyright $\odot 2014$ Sociedade Brasileira de Zootecnia. This is an Open Access article distributed under the terms of the Creative Commons Attribution Non-Commercial License, which permits unrestricted non-commercial use, distribution, and reproduction in any medium, provided the original work is properly cited.
Propolis is a resinous material collected by bees from plant buds and exudates; flavonoids are considered the main class of biologically active phenolic compounds in propolis (Castro et al., 2007). Other compounds are also involved, such as cinnamic acid derivatives and Artepillin C (3, 5-diprenyl-4-hydroxycinnamic acid), one of the major phenolic acids found in Brazilian propolis (Estrada et al., 2008). These phenolic compounds are responsible for the antimicrobial and antioxidant activities of propolis (Santos Neto et al., 2009; Frozza et al., 2013).

However, in order to be officially accepted by major health agencies, propolis requires a chemical standardization to ensure its quality, safety and efficacy (Bankova, 2005); its composition is closely related to the ecology of the flora of each region visited by bees (Park et al., 2002). Furthermore, the concentration of propolis and the alcohol level used to extract the active substances may influence the chemical composition of the propolis extract (Cottica et al., 2011).

In studies involving ruminant metabolism and nutrition, propolis reduced ammonia $\left(\mathrm{NH}_{3}\right)$ production in vitro (Ozturk et al., 2010) and the number of ruminal ciliate protozoa in buffaloes (Ríspoli et al., 2009). Therefore, we evaluated the effects of phenolic compounds from three 
propolis-based products with different concentrations of propolis and levels of alcohol on feed intake, digestibility (ruminal and intestinal) and blood parameters in lactating dairy cows.

\section{Material and Methods}

Four primiparous Holstein cows, 147 days into their lactating period, with a mean body weight (BW) of $550 \pm 34.16 \mathrm{~kg}$, were selected. The cows were cannulated in the rumen, housed in tie stalls, and subjected to two daily milkings $(06.00 \mathrm{~h}$ and $15.00 \mathrm{~h})$. The animals were randomly assigned to a $4 \times 4$ Latin square, with four periods and four treatments, and were treated according to the guidelines of the Committee for Ethical Care and Use of Animals in Research of Universidade Estadual de Maringá (No. 027/2011).

The propolis-based products used in the treatments differed in the concentration of propolis [B and $\mathrm{C}$, between 5.0 and $30.0 \%(\mathrm{w} / \mathrm{v})$ ] and water-alcohol solutions [1 and 3, between 60.0 and $93.8 \%(\mathrm{v} / \mathrm{v})$ of alcohol] and were prepared according to Franco and Bueno (1999). Propolis samples were obtained from the apiary of the Experimental Farm of Iguatemi (FEI), belonging to Universidade Estadual de Maringá, Paraná State, Brazil. The apiary is located within a reserve of eucalyptus (Eucalyptus sp.) plants surrounded by native forest and characterized by the presence of alecrimdo-campo (Baccharis dracunculifolia) plants. Propolisbased products (PBP) are protected under the intellectual property right No. 0605768-3 in Brazil. Propolis extracts were obtained by turbo extraction for $15 \mathrm{~min}$. The extracts were filtered under vacuum, after which the alcohol was removed in a rotary evaporator (Buchi, model RT 210). Subsequently, the extracts were spray-dried in a nebulizer (MSD 1.0, Labmaq, Ribeirão Preto, SP, Brazil) with a capacity of $1 \mathrm{~L} / \mathrm{h}$ and an inlet temperature of $100{ }^{\circ} \mathrm{C}$. The powder of PBP fed to the animals contained this dried propolis extract and an excipient (ground corn and soybean meal). The excipient was used to add volume to the propolis extract and facilitate feeding. The propolis-based products differed both as to the chemical composition and amount of phenolic compounds, resulting in three unique products identified (Table 1).

These compounds were quantified using highperformance liquid chromatography with a photodiode array detector (Alliance HPLC-PDA, Waters Co., Milford, MA, USA).

The experimental diet (Table 2) consisted of $591.9 \mathrm{~g} / \mathrm{kg}$ corn silage and $408.1 \mathrm{~g} / \mathrm{kg}$ concentrate (DM basis), and differed with the inclusion or non-inclusion of the PBP, resulting in four treatments: control (without phenolic compounds from the PBP), PBP B1 (3.81 mg of phenolic compounds $/ \mathrm{kg}$ of ingested DM), PBP C1 $(3.27 \mathrm{mg}$ of phenolic compounds $/ \mathrm{kg}$ of ingested DM), and PBP C3 (1.93 mg of phenolic compounds/kg of ingested DM).

Table 1 - Flavonoids and phenolic acids identified in the propolisbased products $(\mathrm{PBP})^{1,2}$

\begin{tabular}{lccc}
\hline & PBP B1 & PBP C1 & PBP C3 \\
\cline { 2 - 4 } & \multicolumn{3}{c}{ mg/g of dry extract } \\
\hline Chlorogenic acid & n.d. & 0.31 & n.d. \\
Caffeic acid & 5.27 & 6.17 & 4.03 \\
$p$-coumaric acid & 9.30 & 10.59 & 6.85 \\
Benzoic acid & 0.76 & 1.56 & 0.58 \\
CAPE & 3.54 & 3.48 & 1.93 \\
Artepillin C & 9.86 & 9.45 & 6.01 \\
Apigenin & 9.95 & 7.39 & 4.83 \\
Pinocembrin & 6.39 & 4.70 & 3.02 \\
Galangin & 1.93 & n.d. & n.d. \\
Chrysin & 5.07 & 3.44 & 2.09 \\
Acacetin & 5.27 & 4.74 & 2.65 \\
\hline
\end{tabular}

n.d. - not detected.

CAPE - caffeic acid phenethyl ester

${ }^{1}$ Concentrations of propolis (B and C) between 5.0 and $30.0 \%(\mathrm{w} / \mathrm{v})$ in water-alcohol solutions (levels 1 and 3) between 60.0 and $93.8 \%(\mathrm{v} / \mathrm{v})$ of alcohol.

${ }^{2} \mathrm{PBP} \mathrm{B} 1=3.81 \mathrm{mg}$ of phenolic compounds $/ \mathrm{kg}$ of IDM; PBP C1 $=3.27 \mathrm{mg}$ of phenolic compounds $/ \mathrm{kg}$ of IDM; PBP C3 $=1.93 \mathrm{mg}$ of phenolic compounds $/ \mathrm{kg}$ of IDM.

Table 2 - Chemical composition and proportion of ingredients used in the experimental diet

\begin{tabular}{|c|c|c|c|c|c|c|c|c|c|c|}
\hline & \multicolumn{9}{|c|}{$\mathrm{g} / \mathrm{kg}$} & \multirow{2}{*}{ Diet $(\%)$} \\
\hline & $\mathrm{DM}$ & $\mathrm{OP}$ & $\mathrm{CP}$ & $\mathrm{EE}$ & $\mathrm{NDF}$ & $\mathrm{ADF}$ & $\mathrm{TC}$ & NFC & TDN & \\
\hline Corn silage & 292.7 & 962.3 & 72.7 & 30.3 & 606.7 & 337.1 & 856.2 & 249.6 & 634.4 & 59.19 \\
\hline Soybean meal & 898.0 & 935.1 & 462.1 & 14.9 & 182.3 & 100.4 & 433.2 & 250.9 & 806.8 & 19.77 \\
\hline Ground corn & 878.7 & 985.1 & 91.2 & 18.3 & 165.2 & 37.6 & 869.0 & 704.0 & 832.0 & 5.26 \\
\hline Wheat meal & 857.1 & 948.1 & 170.7 & 23.2 & 458.7 & 148.8 & 754.2 & 295.5 & 715.4 & 10.48 \\
\hline Soybean oil & 995.7 & 997.0 & - & 991.3 & - & - & - & - & 2139 & 2.86 \\
\hline V.M. premix ${ }^{1}$ & 990.0 & - & - & - & - & - & - & - & - & 1.98 \\
\hline Limestone & 991.4 & - & - & - & - & - & - & - & - & 0.32 \\
\hline Ammonium sulfate & 990.0 & - & 1,250 & - & - & - & - & - & - & 0.14 \\
\hline Diet & 539.4 & 934.1 & 160.6 & 52.60 & 451.8 & 236.9 & 722.4 & 270.6 & 714.9 & 100.0 \\
\hline
\end{tabular}

DM - dry matter; OM - organic matter; CP - crude protein; EE - ether extract; NDF - neutral detergent fiber; ADF - acid detergent fiber; TC - total carbohydrates; NFC - non-fiber carbohydrates; TDN - total digestible nutrients.

${ }^{1}$ Composition of the vitamin and mineral premix (per kg of product): $146 \mathrm{~g}$ of calcium; $51 \mathrm{~g}$ of phosphorus; $20 \mathrm{~g}$ of sulfur; $33 \mathrm{~g}$ of magnesium; $93 \mathrm{~g}$ of sodium; $28 \mathrm{~g}$ of potassium; $30 \mathrm{mg}$ of cobalt; $400 \mathrm{mg}$ of copper; $10 \mathrm{mg}$ of chromium; 2,000 mg of iron; $40 \mathrm{mg}$ of iodine; 1,350 mg of manganese; $15 \mathrm{mg}$ of selenium; $510 \mathrm{mg}$ of fluoride; $1,700 \mathrm{mg}$ of zinc; 135,000 IU of vitamin A; 78,000 IU of vitamin D3; 450 IU of vitamin E. 
The experimental diet was formulated according to the recommendations of the National Research Council (NRC, 2001) for lactating cows with body weights (BW) of approximately $550 \mathrm{~kg}$, at 21 weeks in lactation, and with an estimated milk yield of $25.0 \mathrm{~kg} /$ day (with a $3.8 \%$ fat content). Net energy for lactation $\left(\mathrm{NE}_{\mathrm{L}}\right)$ was estimated using the following equation: $\mathrm{NE}_{\mathrm{L}}(\mathrm{Mcal} / \mathrm{kg})=0.0245 \times \%$ Total digestible nutrients -0.12 (NRC, 2001), thus generating a value of $1.63 \mathrm{Mcal} / \mathrm{kg}$.

The propolis-based products were inserted in the rumen via a ruminal cannula at the time of feeding, in the form of two daily doses adjusted to $15 \mathrm{~g}$ of the excipient (7.5 g of PBP at $08.00 \mathrm{~h}$ and $7.5 \mathrm{~g}$ at $16.00 \mathrm{~h}$ ). Feed intake was recorded daily and the amounts offered were adjusted to allow for $100 \mathrm{~g} / \mathrm{kg}$ refusals as fed. Cows were weighed at the beginning and end of each experimental period.

The study consisted of four experimental periods of 24 days each (14 days for adaptation, 7 days for sample collection and 3 days for washout). From the second to the fifth day of the collection period, feces and omasal digesta were sampled. Fecal samples $(100 \mathrm{~g})$ were collected directly from the rectum, while omasal digesta samples $(400 \mathrm{~mL})$ were collected by suction of the omasal contents, according to the technique described by Leão et al. (2005). On the first day, the collection was performed at $20.00 \mathrm{~h}$, on the second day at $16.00 \mathrm{~h}$, on the third day at $12.00 \mathrm{~h}$ and on the fourth day at $08.00 \mathrm{~h}$, totaling four samples (feces and digesta) per animal in each period. After the collection period, samples of feed, feces and digesta were dried in a ventilated oven $\left(55^{\circ} \mathrm{C}\right.$ for $72 \mathrm{~h}$ ), ground to a particle size of $1 \mathrm{~mm}$, and mixed in equal quantities to form composite samples. Daily feed intake was estimated as the difference between the supplied feed and refusals in the trough. During the experimental period, samples of feed and refusals were collected and a representative composite sample was drafted per animal in each treatment.

In the last two days of each experimental period, the ruminal fluid was collected via a ruminal cannula to determine $\mathrm{pH}$ and ammonia nitrogen $\left(\mathrm{NH}_{3}-\mathrm{N}\right)$. Urine was collected to determine the efficiency of microbial protein synthesis. The collection began before the first feeding $(08.00 \mathrm{~h})$, which was set as time zero (0) and 2, 4, 6 and $8 \mathrm{~h}$ post-feeding, with five samples obtained per animal per period. To determine the $\mathrm{NH}_{3}-\mathrm{N}$, the material was filtered to obtain $50 \mathrm{~mL}$ of ruminal fluid. Immediately after collection, the $\mathrm{pH}$ was determined and $1 \mathrm{~mL}$ of sulfuric acid $\left(\mathrm{H}_{2} \mathrm{SO}_{4}\right)$ 1:1 was added to the sample. To determine the daily flows of DM and digesta, chromium oxide $\left(\mathrm{Cr}_{2} \mathrm{O}_{3}\right)$ was used as an external marker. Two intra-ruminal doses $(5.0 \mathrm{~g})$ for a total of $10.0 \mathrm{~g} \mathrm{Cr}_{2} \mathrm{O}_{3}$ /day, which was previously weighed in a hygroscopic paper, were provided daily (at $08.00 \mathrm{~h}$ and 16.00 h). $\mathrm{NH}_{3}-\mathrm{N}$ was determined according to Vieira (1980).

Digestive parameters were estimated according to the equations described by Coelho da Silva and Leão (1979). Procedures to determine DM (method no. 934.01), organic matter (OM) (determined by ash content, method no. 924.05), crude protein (CP, method no. 920.87), and to prepare ether extracts (EE, method no. 920.85) were conducted according to AOAC (1990). Neutral detergent fiber (NDF) was analyzed with the procedure of Van Soest et al. (1991) with amylase and sodium sulfite. Acid detergent fiber (ADF) was determined according to method no. 973.18 (AOAC, 1990). Total carbohydrates (TC) were obtained using the following equation: $\mathrm{TC}=100-(\% \mathrm{CP}+\% \mathrm{EE}$ $+\%$ Ash), (Sniffen et al., 1992). Non-fiber carbohydrates (NFC) were determined by the difference between TC and NDF (without correction for protein). The TDN content of the experimental diets was calculated using the following equation: $\% \mathrm{TDN}=\% \mathrm{DCP}+\% \mathrm{DNDF}+\% \mathrm{DNFC}+\%(\mathrm{DEE}$ $\times 2.25)$, in which $\mathrm{DCP}=$ digestible crude protein, $\mathrm{DNDF}=$ digestible neutral detergent fiber, DNFC $=$ digestible nonfiber carbohydrates, DEE = digestible ether extract.

In order to determine microbial production, spot urine samples were collected approximately four hours after feeding, during voluntary urination. The samples were filtered to prevent possible contamination. An aliquot of $10 \mathrm{~mL}$ of urine was diluted in $40 \mathrm{~mL}$ of $0.036 \mathrm{~N}$ sulfuric acid $\left(\mathrm{H}_{2} \mathrm{SO}_{4}\right)$ to avoid bacterial destruction of purine derivatives and uric acid precipitation. Urine samples were stored under refrigeration $\left(5^{\circ} \mathrm{C}\right)$ and subsequently analyzed for concentrations of creatinine, allantoin, uric acid, and urea. On the same day, samples of milk were collected from the first and second milking cycles, which were combined into a composite sample. A $10 \mathrm{~mL}$ aliquot of milk was mixed with $5 \mathrm{~mL}$ of $25 \%$ trichloroacetic acid $\left(\mathrm{C}_{2} \mathrm{HCl}_{3} \mathrm{O}_{2}\right)$, filtered, and stored at $5{ }^{\circ} \mathrm{C}$ for subsequent analysis of urea and allantoin.

Allantoin was analyzed using the method described by Chen and Gomes (1992). To determine creatinine, uric acid, and urea, analyses were performed using commercial kits (Labtest). From the concentration of creatinine in the spot urine sample, the urinary volume was estimated (L) by dividing the daily excretion of creatinine $(\mathrm{mg} / \mathrm{kg} \mathrm{BW})$ by creatinine concentration $(\mathrm{mg} / \mathrm{L})$. For the determination of daily creatinine excretion per $\mathrm{kg}$ of $\mathrm{BW}$, the average value of $23.41 \mathrm{mg} / \mathrm{kg}$ of BW was used as discussed by Oliveira et al. (2001), who determined the creatinine excretions of Holstein cows fed diets comprising 60:40 forage-toconcentrate ratio; these characteristics are similar to those in our study. The microbial nitrogen $(\mathrm{N})$ production was calculated from the amount of absorbed purines, which was 
estimated as the sum of the excretion of purine derivatives (PD) in milk and urine, after which the synthesis of microbial $\mathrm{N}$ compounds in the rumen was calculated based on the absorbed purine, according to Chen and Gomes (1992). Microbial protein synthesis (MPS) was estimated by multiplying the microbial $\mathrm{N}$ synthesis by 6.25 , while the efficiency of microbial protein synthesis (EMPS) was determined as follows: EMPS $(\mathrm{g} / \mathrm{kg})=$ MPS $(\mathrm{g}) / \mathrm{TDNI}(\mathrm{kg})$, in which TDNI $=$ total digestible nutrients intake.

To determine blood urea, blood samples were collected on day 21 of each experimental period, $4 \mathrm{~h}$ after the first feeding. Immediately after sampling, the tubes (containing heparin) were centrifuged at $2500 \mathrm{rpm}$ for $15 \mathrm{~min}$ to obtain the plasma. The centrifuged samples were transferred to labeled plastic tubes, stored in an insulated box, and immediately transported to a laboratory, where analysis was performed using a commercial kit in an automatic analyzer for blood biochemistry (Vitalab Selectra, Merck \& Co. Inc., Whitehouse Station, NJ, USA).

Data were interpreted with analysis of variance by using the GLM procedure of Statistical Analysis System (SAS, version 8.01). The mathematical model used for the analysis was as follows: $\mathrm{Y}_{\mathrm{ijk}}=\mu+\mathrm{A}_{\mathrm{i}}+\mathrm{P}_{\mathrm{j}}+\mathrm{T}_{\mathrm{k}}+\mathrm{e}_{\mathrm{ijk}}$, in which $Y_{i j k}=$ observed variables, $\mu=$ overall mean, $A_{i}=$ effect of animal $\mathrm{i}$, ranging from 1 to $4 ; \mathrm{P}_{\mathrm{j}}=$ effect of period $j$ varying from 1 to $4 ; T_{k}=k$ effect of the treatment, ranging from 1 to 4; and $\mathrm{e}_{\mathrm{ijk}}=$ random error. Statistical analyses of ruminal parameters $\left(\mathrm{pH}\right.$ and $\left.\mathrm{NH}_{3}-\mathrm{N}\right)$ were performed using a split-plot design, with treatments as plots and collection times as subplots. Differences between treatment means were determined using Tukey's HSD test. Values with $\alpha=0.05$ were considered statistically significant.

\section{Results}

The amount of PBP supplied to the cows resulted in a variation in the intake of flavonoids and phenolic acids per $\mathrm{kg}$ of ingested DM (Table 3). The PBP C3 had the lowest concentration of total flavonoids and phenolic acids, resulting in a lower intake of these compounds.
No effect $(\mathrm{P}>0.05)$ on DM intake and nutrients was observed between treatments, but a high NDF intake $(\mathrm{P}=0.009)$ was observed in the PBP B1 treatment (Table 4). The inclusion of PBP in the diet affected $(\mathrm{P}<0.05)$ the ruminal digestibility of $\mathrm{DM}, \mathrm{OM}, \mathrm{CP}$, and $\mathrm{TC}$, with lower ruminal digestibility of these nutrients in the PBP C1 treatment compared with that in the control. Likewise, the inclusion of PBP had significant effects $(\mathrm{P}<0.05)$ on the intestinal digestibility of $\mathrm{DM}, \mathrm{OM}, \mathrm{CP}$, and TC (Table 4). For CP, greater intestinal digestibility $(\mathrm{P}<0.05)$ was observed when PBP B1 was present compared with control. The diets containing PBP B1 and $\mathrm{C} 1$ presented higher intestinal digestibility of DM, OM, and TC $(\mathrm{P}<0.05)$ than control diet.

The different PBP did not affect DM, OM, CP, NDF, and TDN ( $>0.05)$ (Table 5) compared with control diet. Among the propolis-based products, PBP B1 was responsible for greater total digestibility of DM, OM, NDF, ADF and TC $(\mathrm{P}<0.05)$ compared with PBP $\mathrm{C} 3$, but did not differ $(\mathrm{P}>0.05)$ from those in the $\mathrm{PBP} \mathrm{C} 1$.

Inclusion of $\mathrm{PBP}$ in the diet had no effect $(\mathrm{P}>0.05)$ in terms of the interaction between treatment and collection time for rumen $\mathrm{pH}$ (Figure 1). Rumen $\mathrm{pH}$ exhibited a quadratic curve as a function of time in terms of hours post-feeding $\left(\mathrm{pH}=6.86944-0.42107 \mathrm{X}+0.042898 \mathrm{X}^{2}\right.$, $\mathrm{r}^{2}=0.736 \%$ ), with an estimated minimum $\mathrm{pH}$ of 5.83 at $4.9 \mathrm{~h}$.

No interaction was observed between treatment and collection time $(\mathrm{P}>0.05)$ for $\mathrm{NH}_{3}-\mathrm{N}$ concentration in the rumen fluid (Figure 2); however, the mean concentrations of $\mathrm{NH}_{3}-\mathrm{N}$ in the rumen were influenced $(\mathrm{P}<0.05)$ by including PBP C1 in the diet (Table 6).

The behavior of $\mathrm{NH}_{3}-\mathrm{N}$ as a function of time after feeding was quadratic, in which $\mathrm{NH}_{3}-\mathrm{N}=16.4810+$ $7.96253 \mathrm{X}-0.871208 \mathrm{X}^{2}$, with $\mathrm{r}^{2}=0.951 \%$. The highest estimated concentration of $\mathrm{NH}_{3}-\mathrm{N}$ in the ruminal fluid was $34.67 \mathrm{mg} / \mathrm{dL}$ at $4.6 \mathrm{~h}$ after feeding and the minimum concentration was $16.48 \mathrm{mg} / \mathrm{dL}$ at $0 \mathrm{~h}$.

The propolis-based products had no effect $(\mathrm{P}>0.05)$ on the excretion of purine derivatives in urine and milk,

Table 3 - Total flavonoids and phenolic acids quantified in the propolis-based products (PBP) supplied daily to dairy cows

\begin{tabular}{|c|c|c|c|c|c|}
\hline \multirow{2}{*}{ Compounds } & \multicolumn{3}{|c|}{ Propolis-based product ${ }^{1,2}(\mathrm{mg} / \mathrm{kg}$ IDM) } & \multirow{2}{*}{ P-value } & \multirow{2}{*}{ SEM } \\
\hline & PBP B1 & PBP C1 & PBP C3 & & \\
\hline Total flavonoids & $2.81 \mathrm{a}$ & $2.14 \mathrm{~b}$ & $1.22 \mathrm{c}$ & $<0.001$ & 0.028 \\
\hline Artepillin C and CAPE & $0.40 \mathrm{a}$ & $0.41 \mathrm{a}$ & $0.25 b$ & $<0.001$ & 0.006 \\
\hline Total phenolic acids ${ }^{3}$ & $1.00 \mathrm{~b}$ & $1.13 \mathrm{a}$ & $0.71 \mathrm{c}$ & $<0.001$ & 0.017 \\
\hline
\end{tabular}

Different letters in the same row are statistically different $(\mathrm{P}<0.05)$ by Tukey's test.

IDM - ingested dry matter; SEM - standard error of the mean.

${ }^{1}$ Concentrations of propolis (B and C) between 5.0 and 30.0\% (w/v) in water-alcohol solutions (levels 1 and 3) between 60.0 and $93.8 \%$ (v/v) of alcohol.

${ }^{2} \mathrm{PBP}$ B $1=3.81 \mathrm{mg}$ of phenolic compounds $/ \mathrm{kg}$ of IDM; PBP C1 = 3.27 mg of phenolic compounds $/ \mathrm{kg}$ of IDM; PBP C3 = $1.93 \mathrm{mg}$ of phenolic compounds $/ \mathrm{kg}$ of IDM

${ }^{3}$ Sum of the phenolic acids grouped at the beginning of the chromatogram with CAPE and Artepillin C. 
Table 4 - Feed intake, ruminal digestibility ${ }^{1}$ and intestinal digestibility ${ }^{2}$ of DM and nutrients in dairy cows fed a diet with (PBP) or without $(\mathrm{CON})$ addition of phenolic compounds from propolis

\begin{tabular}{|c|c|c|c|c|c|c|}
\hline \multirow{2}{*}{ Parameters } & \multicolumn{4}{|c|}{ Treatments $^{3}$} & \multirow{2}{*}{ SEM } & \multirow{2}{*}{ P-value } \\
\hline & $\mathrm{CON}$ & PBP B1 & PBP C1 & PBP C3 & & \\
\hline \multicolumn{7}{|c|}{ Dry matter } \\
\hline Intake (kg/day) & 15.66 & 16.34 & 15.60 & 15.31 & 0.212 & 0.064 \\
\hline Omasal flow (kg/day) & 7.62 & 8.11 & 8.04 & 7.44 & 0.178 & $>0.100$ \\
\hline Ruminal digestibility (kg/kg) & $0.513 \mathrm{a}$ & $0.503 \mathrm{ab}$ & $0.483 b$ & $0.514 \mathrm{a}$ & 0.010 & 0.022 \\
\hline Fecal flow (kg/day) & 4.87 & 4.61 & 4.64 & 4.82 & 0.150 & 0.197 \\
\hline Intestinal digestibility $(\mathrm{kg} / \mathrm{kg})$ & $0.362 b$ & $0.430 \mathrm{a}$ & $0.422 \mathrm{a}$ & $0.352 b$ & 0.021 & 0.004 \\
\hline \multicolumn{7}{|c|}{ Organic matter } \\
\hline Intake (kg/day) & 14.60 & 15.23 & 14.55 & 14.28 & 0.194 & 0.062 \\
\hline Omasal flow (kg/day) & $6.46 \mathrm{ab}$ & $6.84 a$ & $6.80 \mathrm{ab}$ & $6.26 b$ & 0.136 & 0.063 \\
\hline Ruminal digestibility (kg/kg) & $0.557 \mathrm{a}$ & $0.550 \mathrm{a}$ & $0.532 b$ & $0.561 \mathrm{a}$ & 0.009 & 0.013 \\
\hline Fecal flow (kg/day) & 4.25 & 4.00 & 4.05 & 4.23 & 0.135 & 0.125 \\
\hline Intestinal digestibility $(\mathrm{kg} / \mathrm{kg})$ & $0.343 b$ & $0.414 \mathrm{a}$ & $0.404 \mathrm{a}$ & $0.323 b$ & 0.024 & 0.008 \\
\hline \multicolumn{7}{|c|}{ Crude protein } \\
\hline Intake (kg/day) & 2.51 & 2.67 & 2.52 & 2.46 & 0.047 & 0.079 \\
\hline Omasal flow (kg/day) & $1.87 \mathrm{~b}$ & $2.16 \mathrm{a}$ & $2.05 \mathrm{ab}$ & $1.99 \mathrm{ab}$ & 0.055 & 0.048 \\
\hline Ruminal digestibility (kg/kg) & $0.256 \mathrm{a}$ & $0.189 b$ & $0.182 b$ & $0.190 b$ & 0.023 & 0.007 \\
\hline Fecal flow (kg/day) & 0.63 & 0.64 & 0.69 & 0.64 & 0.019 & 0.214 \\
\hline Intestinal digestibility (kg/kg) & $0.657 \mathrm{~b}$ & $0.700 \mathrm{a}$ & $0.663 \mathrm{~b}$ & $0.678 \mathrm{ab}$ & 0.015 & 0.030 \\
\hline \multicolumn{7}{|c|}{ Neutral detergent fiber } \\
\hline Intake (kg/day) & $6.84 b$ & $7.15 \mathrm{a}$ & $6.81 \mathrm{~b}$ & $6.61 b$ & 0.070 & 0.009 \\
\hline Omasal flow (kg/day) & $2.97 \mathrm{ab}$ & $3.20 \mathrm{a}$ & $3.23 \mathrm{a}$ & $2.88 \mathrm{~b}$ & 0.071 & 0.031 \\
\hline Ruminal digestibility (kg/kg) & 0.565 & 0.552 & 0.525 & 0.563 & 0.015 & 0.113 \\
\hline Fecal flow (kg/day) & 2.92 & 2.70 & 2.74 & 2.92 & 0.106 & 0.375 \\
\hline Intestinal digestibility $(\mathrm{kg} / \mathrm{kg})$ & $0.018 \mathrm{ab}$ & $0.158 \mathrm{a}$ & $0.152 \mathrm{a}$ & $0.001 \mathrm{~b}$ & 0.037 & 0.037 \\
\hline \multicolumn{7}{|c|}{ Total carbohydrates } \\
\hline Intake (kg/day) & 11.26 & 11.68 & 11.19 & 11.00 & 0.137 & 0.059 \\
\hline Omasal flow (kg/day) & $4.05 \mathrm{ab}$ & $4.37 \mathrm{a}$ & $4.30 \mathrm{a}$ & $3.87 b$ & 0.100 & 0.041 \\
\hline Ruminal digestibility (kg/kg) & $0.639 \mathrm{a}$ & $0.625 \mathrm{ab}$ & $0.615 b$ & $0.648 \mathrm{a}$ & 0.011 & 0.027 \\
\hline Fecal flow (kg/day) & 3.54 & 3.28 & 3.29 & 3.52 & 0.131 & 0.396 \\
\hline Intestinal digestibility (kg/kg) & $0.126 b$ & $0.247 \mathrm{a}$ & $0.235 \mathrm{a}$ & $0.089 \mathrm{~b}$ & 0.044 & 0.009 \\
\hline
\end{tabular}

Different letters in the same row are statistically different $(\mathrm{P}<0.05)$ by Tukey's test.

SEM - standard error of the mean; IDM - ingested dry matter.

${ }^{1}$ Based on the amount ingested.

${ }^{2}$ Based on the amount that reached the duodenum.

${ }^{3} \mathrm{PBP}$ B $1=3.81 \mathrm{mg}$ of phenolic compounds $/ \mathrm{kg}$ of IDM; PBP C1 $=3.27 \mathrm{mg}$ of phenolic compounds $/ \mathrm{kg}$ of IDM; PBP C3 = $1.93 \mathrm{mg}$ of phenolic compounds $/ \mathrm{kg}$ of IDM.

Table 5 - Total digestibility of nutrients and total digestible nutrients in dairy cows fed diets with (PBP) or without (CON) addition of phenolic compounds from propolis

\begin{tabular}{|c|c|c|c|c|c|c|}
\hline \multirow{2}{*}{ Parameters } & \multicolumn{4}{|c|}{ Treatments $^{1}(\mathrm{~kg} / \mathrm{kg})$} & \multirow{2}{*}{ SEM } & \multirow{2}{*}{ P-value } \\
\hline & $\mathrm{CON}$ & PBP B1 & PBP C1 & PBP C3 & & \\
\hline DM total digestibility & $0.689 \mathrm{ab}$ & $0.717 \mathrm{a}$ & $0.702 \mathrm{ab}$ & $0.685 b$ & 0.008 & 0.034 \\
\hline OM total digestibility & $0.709 \mathrm{ab}$ & $0.737 \mathrm{a}$ & $0.721 \mathrm{ab}$ & $0.703 b$ & 0.008 & 0.030 \\
\hline CP total digestibility & $0.745 \mathrm{ab}$ & $0.760 \mathrm{a}$ & $0.725 b$ & $0.739 \mathrm{ab}$ & 0.009 & 0.022 \\
\hline EE total digestibility & 0.912 & 0.920 & 0.916 & 0.908 & 0.008 & 0.385 \\
\hline NDF total digestibility & $0.573 \mathrm{ab}$ & $0.622 \mathrm{a}$ & $0.598 \mathrm{ab}$ & $0.558 b$ & 0.016 & 0.025 \\
\hline ADF total digestibility & 0.552 & 0.591 & 0.570 & 0.526 & 0.018 & 0.054 \\
\hline TC total digestibility & 0.685 & 0.718 & 0.706 & 0.680 & 0.011 & 0.053 \\
\hline NFC total digestibility & 0.860 & 0.870 & 0.881 & 0.867 & 0.008 & 0.316 \\
\hline Total digestible nutrients & $0.719 \mathrm{ab}$ & $0.747 \mathrm{a}$ & $0.732 \mathrm{ab}$ & $0.712 b$ & 0.008 & 0.022 \\
\hline
\end{tabular}

Different letters in the same row are statistically different $(\mathrm{P}<0.05)$ by Tukey's test.

SEM - standard error of the mean; IDM - ingested dry matter.

$\mathrm{DM}$ - dry matter, OM - organic matter, CP - crude protein, EE - ether extract, NDF - neutral detergent fiber, ADF - acid detergent fiber, TC - total carbohydrates, NFC - non-fiber carbohydrates.

${ }^{1} \mathrm{PBP} \mathrm{B} 1=3.81 \mathrm{mg}$ of phenolic compounds $/ \mathrm{kg}$ of IDM, PBP C1 = $3.27 \mathrm{mg}$ of phenolic compounds $/ \mathrm{kg}$ of IDM, PBP C3 = $1.93 \mathrm{mg}$ of phenolic compounds $/ \mathrm{kg}$ of IDM. 


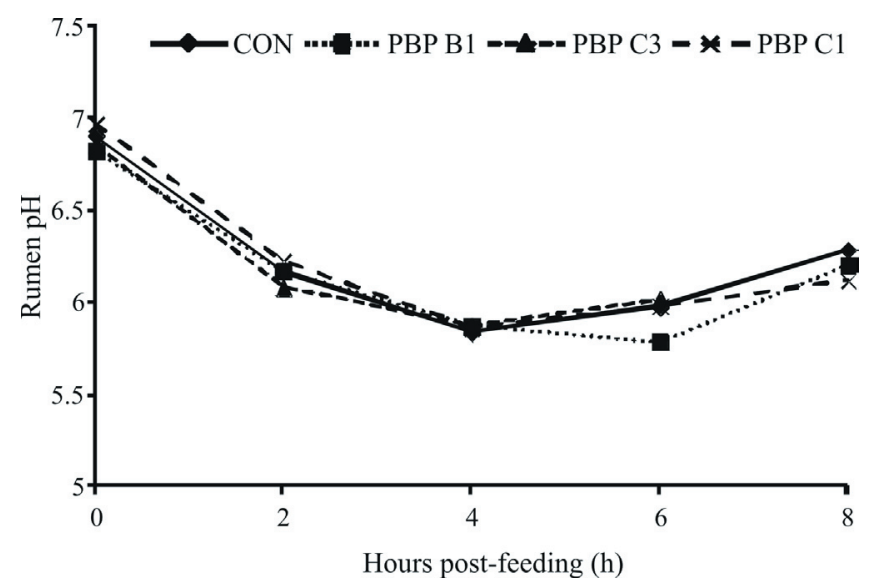

Figure 1 - Ruminal $\mathrm{pH}$ as affected by hours post-feeding in dairy cows fed diets with (PBP) or without (CON) addition of phenolic compounds from propolis.

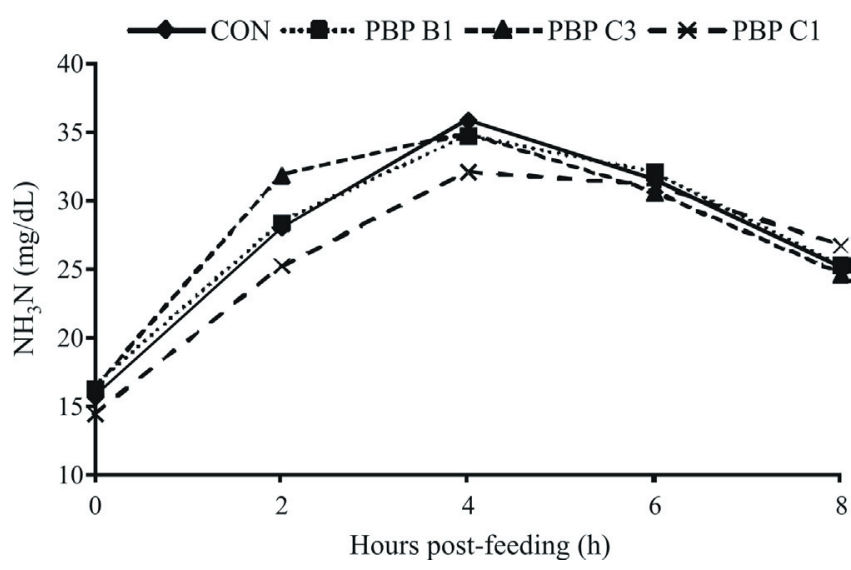

Figure $2-\mathrm{NH}_{3}-\mathrm{N}$ concentration in the rumen fluid as affected by hours post-feeding in dairy cows fed diets with (PBP) or without $(\mathrm{CON})$ addition of phenolic compounds from propolis.

Table 6 - Ruminal $\mathrm{pH}$ and ammonia nitrogen $\left(\mathrm{NH}_{3}-\mathrm{N}\right)$ of dairy cows fed diets with (PBP) or without (CON) addition of phenolic compounds from propolis

\begin{tabular}{|c|c|c|c|c|c|c|}
\hline \multirow{2}{*}{ Parameters } & \multicolumn{4}{|c|}{ Treatments $^{1}$} & \multirow{2}{*}{ P-value } & \multirow{2}{*}{ SEM } \\
\hline & $\mathrm{CON}$ & PBP B1 & PBP C1 & PBP C3 & & \\
\hline $\mathrm{pH}$ & 6.24 & 6.17 & 6.22 & 6.23 & 0.158 & 0.053 \\
\hline $\mathrm{N}-\mathrm{NH}_{3}(\mathrm{mg} / \mathrm{dL})$ & $27.27 \mathrm{a}$ & $27.37 \mathrm{a}$ & $25.94 b$ & $27.63 \mathrm{a}$ & 0.002 & 0.183 \\
\hline
\end{tabular}

Different letters in the same row are statistically different $(\mathrm{P}<0.05)$ by Tukey's test.

SEM -standard error of the mean; IDM - ingested dry matter.

${ }^{1} \mathrm{PBP}$ B $1=3.81 \mathrm{mg}$ of phenolic compounds $/ \mathrm{kg}$ of IDM; PBP C1 $=3.27 \mathrm{mg}$ of phenolic compounds $/ \mathrm{kg}$ of IDM; PBP C3 = $1.93 \mathrm{mg}$ of phenolic compounds $/ \mathrm{kg}$ of IDM.

Table 7 - Urinary volume, urinary excretion of purine derivates, microbial protein synthesis and efficiency of microbial protein synthesis of dairy cows fed diets with (PBP) or without $(\mathrm{CON})$ addition of phenolic compounds from propolis

\begin{tabular}{|c|c|c|c|c|c|}
\hline \multirow{2}{*}{ Parameters } & \multicolumn{4}{|c|}{ Treatments $^{1}$} & \multirow{2}{*}{ SEM } \\
\hline & $\mathrm{CON}$ & PBP B1 & PBP C1 & PBP C3 & \\
\hline \multirow[t]{2}{*}{ Urinary volume (L/day) } & 16.85 & 16.57 & 18.12 & 19.38 & 1.48 \\
\hline & \multicolumn{4}{|c|}{ Purine derivatives (PD) } & \\
\hline Allantoin (mmol/day) & 232.33 & 215.82 & 274.16 & 240.82 & 32.51 \\
\hline Uric acid (mmol/day) & 24.71 & 24.20 & 26.70 & 30.22 & 1.57 \\
\hline Milk PD (mmol/day) & 16.12 & 16.51 & 17.23 & 16.36 & 0.30 \\
\hline Purine derivatives (mmol/day) & 273.16 & 256.52 & 318.09 & 287.39 & 34.11 \\
\hline Allantoin (\% of total PD) & 84.67 & 83.78 & 85.97 & 83.15 & 1.06 \\
\hline Uric acid ( $\%$ of total PD) & 9.25 & 9.59 & 8.47 & 10.73 & 0.49 \\
\hline \multirow[t]{2}{*}{ Milk PD ( $\%$ of total PD) } & 6.08 & 6.63 & 5.56 & 6.12 & 0.58 \\
\hline & \multicolumn{4}{|c|}{ Absorbed microbial purines } & \\
\hline \multirow[t]{2}{*}{$\mathrm{mmol} / \mathrm{day}$} & 270.66 & 251.57 & 323.81 & 287.64 & 40.11 \\
\hline & \multicolumn{4}{|c|}{ Microbial nitrogen compounds } & \\
\hline \multirow[t]{2}{*}{ g/day } & 196.77 & 182.89 & 235.41 & 209.11 & 29.16 \\
\hline & \multicolumn{4}{|c|}{ Microbial protein synthesis (MPS) } & \\
\hline \multirow[t]{2}{*}{ g/day } & 1229.81 & 1143.06 & 1471.30 & 1306.99 & 182.28 \\
\hline & \multicolumn{4}{|c|}{ Efficiency of microbial protein synthesis } & \\
\hline $\mathrm{g}$ MPS $/ \mathrm{kg}$ of total digestible nutrients & 111.52 & 104.56 & 126.76 & 116.71 & 16.74 \\
\hline
\end{tabular}

SEM - standard error of the mean; IDM - ingested dry matter.

${ }^{1} \mathrm{PBP}$ B1 $=3.81 \mathrm{mg}$ of phenolic compounds $/ \mathrm{kg}$ of IDM; PBP C1 = $3.27 \mathrm{mg}$ of phenolic compounds $/ \mathrm{kg}$ of IDM; PBP C3 = $1.93 \mathrm{mg}$ of phenolic compounds $/ \mathrm{kg}$ of IDM.

on microbial protein synthesis (g/day), or on microbial efficiency (g MPS $/ \mathrm{kg}$ of TDN) (Table 7). Likewise, the efficiency of microbial synthesis was not affected $(\mathrm{P}>0.05)$ by inclusion of PBP in the diet.
The addition of PBP did not change $\mathrm{N}$ utilization (Table 8), which averaged 18.72, 14.63, and $874.12 \mathrm{mg} / \mathrm{dL}$, respectively, for blood urea $\mathrm{N}$ (BUN), milk urea $\mathrm{N}$ (MUN), and urine urea $\mathrm{N}$ (UUN). 
Table 8 - Mean concentrations of urea and urea nitrogen in the blood, milk and urine of dairy cows fed diets with (PBP) or without (CON) addition of phenolic compounds from propolis

\begin{tabular}{|c|c|c|c|c|c|c|}
\hline \multirow{2}{*}{ Parameters } & \multicolumn{4}{|c|}{ Treatments $^{1}(\mathrm{~kg} / \mathrm{kg})$} & \multirow{2}{*}{ SEM } & \multirow{2}{*}{ P-value } \\
\hline & $\mathrm{CON}$ & PBP B1 & PBP C1 & PBP C3 & & \\
\hline Blood urea $\mathrm{mg} / \mathrm{dL}$ & 38.50 & 42.75 & 40.75 & 38.25 & 1.42 & 0.186 \\
\hline Milk urea mg/dL & 31.40 & 33.42 & 31.26 & 29.16 & 1.65 & 0.415 \\
\hline Urine urea $\mathrm{mg} / \mathrm{dL}$ & 1790.0 & 1832.5 & 2000.0 & 1860.0 & 188.83 & 0.769 \\
\hline Blood urea nitrogen $\mathrm{mg} / \mathrm{dL}$ & 17.99 & 19.98 & 19.04 & 17.87 & 0.66 & 0.186 \\
\hline Milk urea nitrogen mg/dL & 14.68 & 15.62 & 14.61 & 13.63 & 0.77 & 0.415 \\
\hline Milk protein $(\%)$ & 3.76 & 3.77 & 3.63 & 3.61 & 0.11 & 0.980 \\
\hline
\end{tabular}

SEM - standard error of the mean; IDM - ingested dry matter.

${ }^{1} \mathrm{PBP}$ B1 $=3.81 \mathrm{mg}$ of phenolic compounds $/ \mathrm{kg}$ of IDM; PBP C1 $=3.27 \mathrm{mg}$ of phenolic compounds $/ \mathrm{kg}$ of IDM; PBP C3 = $1.93 \mathrm{mg}$ of phenolic compounds $/ \mathrm{kg}$ of IDM.

\section{Discussion}

In general, PBP do not appear to affect feed intake when propolis is supplied in the form of powder, as verified in feedlot cattle diets (Valero, 2010; Simioni, 2011; Zawadzki et al., 2011; Aguiar et al., 2012) and forage-based diets (Prado et al., 2010). However, Loureiro et al. (2007) found a reduction in DM intake in lambs fed diets containing 15 and $30 \mathrm{mg}$ of propolis extract/kg of BW as compared with control. In all likelihood, the forms in which propolis is included in the diet (powder, liquid, or directly in the rumen) and dosages, together with the type of diet and animal, are responsible for the diverse effects on DM intake.

In our study, it was observed that the three PBP reduced the ruminal digestibility of $\mathrm{CP}(\mathrm{P}=0.007)$, corroborating the findings of Prado et al. (2010). Similarly, Simioni (2011) observed lower ruminal digestibility of $\mathrm{CP}$ in cows fed $\mathrm{PBP}$ $\mathrm{C} 1(\mathrm{P}<0.05)$ compared with those fed monensin, but this was not significantly different from that in the control. These data suggest that $\mathrm{PBP}$ enhance $\mathrm{N}$ metabolism in the rumen, by reducing the populations of $\mathrm{NH}_{3}$-producing bacteria, and therefore, increasing the flow of microbial protein to the intestine $(\mathrm{P}=0.048)$. Furthermore, PBP B1 improved the intestinal digestibility of $\mathrm{CP}$ compared with control, which is beneficial to the animal, because maximizing the capture of degradable $\mathrm{N}$ not only improves the supply of amino acids to the small intestine but also decreases $\mathrm{N}$ losses (Bach et al., 2005). Furthermore, Aguiar et al. (2013) found that the propolis extracts $\mathrm{B} 1$ and $\mathrm{C} 1$ inhibited the growth of the hyper-ammonia-producing bacteria Peptostreptococcus sp. D1 and Clostridium aminophilum in vitro. Thus, PBP may act on the main ammonia-producing bacteria, reducing energy loss and increasing the flow of microbial protein to the intestine, where these proteins are absorbed.

The inclusion of PBP in the diet inhibited ruminal digestibility and changed the primary site of digestion (rumen) for most nutritional components, which was reflected in significant increases in the intestinal digestibility of DM, OM, and TC for PBP B1 and $\mathrm{C} 1$ compared with control.

The chemical composition and amount of phenolic compounds in the PBP influenced the total digestibility of DM, OM, CP, NDF, and TDN (Table 5). However, Aguiar et al. (2012) reported no effects of PBP C1 on the total digestibility of DM, OM, NDF, TC, and TDN compared with control treatment. It is noteworthy that the PBP dosage used by Aguiar et al. (2012) was two times lower than that used in our study. In this study, the higher total digestibility of DM and OM linked to the inclusion of $\mathrm{PBP} \mathrm{B} 1$ rather than $\mathrm{PBP} \mathrm{C} 3$ could be attributed to the daily supplemented amounts of flavonoids (PBP B1 = $2.81 \mathrm{mg} / \mathrm{kg}$ of IDM vs. PBP C3 $=1.22 \mathrm{mg} / \mathrm{kg}$ of IDM) and phenolic acids (PBP B1 $=1.00 \mathrm{mg} / \mathrm{kg}$ of IDM vs. PBP C3 $=0.71 \mathrm{mg} / \mathrm{kg}$ of IDM).

New evidence involving the mechanisms behind the antimicrobial activity of flavonoids has been discovered: inhibition of cell wall and cell membrane synthesis (Cushnie and Lamb, 2011). Accordingly, a single flavonoid may have different mechanisms of action; in propolis, the synergy between phenolic compounds may hinder the understanding of the antimicrobial activity of a particular compound. Among the phenolic acids, the presence of caffeic acid phenethyl ester (CAPE) and Artepillin $\mathrm{C}$ was noteworthy. Both the compounds possess strong antimicrobial activity, but their mechanisms of action have not been fully elucidated (Estrada et al., 2008; Bankova, 2009).

The observation that the total digestibility of $\mathrm{CP}$ was higher in the PBP B1 than in the PBP $\mathrm{C} 1$ treatment $(\mathrm{P}<0.05)$ was in contrast with the results of previous studies on PBP, which detected no significant differences between various extracts and/or dosages of PBP (Valero, 2010; Simioni, 2011; 
Aguiar et al., 2012). However, effects on the ruminal metabolism of $\mathrm{CP}$ as well as an increase in microbial protein flow to the intestine were observed (Prado et al., 2010).

Effects of PBP on the total digestibility of EE have been shown, although this was not observed in the present study. Prado et al. (2010) revealed that the total digestibility of $\mathrm{EE}$ in cattle was reduced by adding PBP $\mathrm{C} 1$ compared with the control diet and monensin. However, these results contradict those found by Valero (2010), indicating a higher total digestibility of EE with PBP C1 compared with control diet and monensin. Furthermore, Simioni (2011) reported a tendency $(\mathrm{P}=0.08)$ of $\mathrm{PBP} \mathrm{C} 1$ to increase the total digestibility of EE. However, it is important to consider the forage-to-concentrate ratio supplied to the animals and the dosages of PBP, both of which varied among the cited experiments. Prado et al. (2010) supplied forage-based diets, whereas Valero (2010) and Simioni (2011) used highly concentrate diets. Generally, Anaerovibrio lipolytica would be expected to dominate ruminal lipase activity in animals receiving mainly concentrate feeds, but because A. lipolytica lacks the ability to hydrolyze galacto- and phospholipids, other lipolytic species would be expected to predominate in grazing animals. An example is Butyrivibrio spp., which hydrolyzes phospho- and galactolipids but does not break down triacylglycerols, the main substrate of A. lipolytica (Lourenço et al., 2010). Therefore, it is possible that Butyrivibrio spp. is more sensitive to propolis, with consequent effects on lipid digestion.

The PBP B1 treatment improved the total digestibility of DM, OM, NDF, ADF and TC $(\mathrm{P}<0.05)$ compared with PBP $\mathrm{C} 3$, but did not differ $(\mathrm{P}>0.05)$ from PBP $\mathrm{C} 1$. According to Prado et al. (2010), the observed differences among the PBP may be related not only to the concentration of propolis, but also to the concentrations of alcohol used in the extraction solvent. The authors concluded that higher alcohol concentrations might facilitate the solubilization of resin and wax present in propolis, which induces the release of phenolic compounds. This hypothesis is reinforced by the results obtained in our study, where PBP C3 showed lower concentrations of flavonoids and phenolic acids than PBP B1 and C1.

The propolis-based products did not affect rumen $\mathrm{pH}$. However, Simioni (2011) found that rumen $\mathrm{pH}$ remained higher $(\mathrm{P}<0.05)$ in diets containing $\mathrm{PBP}$ at different doses (two doses of PBP B1/day and three doses of PBP C1/day) compared with that containing monensin, but did not differ from the control diet.

The mean concentrations of $\mathrm{NH}_{3}-\mathrm{N}$ in the rumen were influenced by the inclusion of PBP in the diet, but this was not observed in previous studies (Prado et al., 2010;
Simioni, 2011). However, propolis appeared to reduce $\mathrm{NH}_{3}$ production. Ozturk et al. (2010) investigated the effects of different concentrations of an ethanolic propolis extract on microbial fermentation in vitro and found that the concentration of $\mathrm{NH}_{3}-\mathrm{N}$ in the rumen fluid was reduced to $24 \%$ and $39 \%$ of the control value with the addition of low and high concentrations of the propolis extract, respectively. Similarly, Oeztuerk et al. (2010) investigated the effects of nisin and propolis on in vitro fermentation of a 60:40 forageto-concentrate diet and observed that both substances decreased $\mathrm{NH}_{3}$ production. Likewise, Aguiar et al. (2013) observed that propolis extracts $\mathrm{B} 1$ and $\mathrm{C} 1$ displayed strong antimicrobial activity against hyper-ammonia-producing rumen bacteria; this may have contributed to the reduction of $\mathrm{NH}_{3}$ production in the rumen.

It is important to emphasize the role of protozoa since they are known to be sensitive to PBP (Ríspoli et al., 2009). The most important aspect of protozoa is their ability to engulf large molecules, such as proteins, carbohydrates, and rumen bacteria (Van Soest, 1994). Because protozoa are not able to use $\mathrm{NH}_{3}-\mathrm{N}$, a fraction of the engulfed insoluble protein returns to the ruminal fluid in the form of soluble protein (Dijkstra, 1994). Thus, defaunation decreases the concentration of $\mathrm{NH}_{3}-\mathrm{N}$ in the rumen (Eugene et al., 2004). Therefore, propolis-based products (especially PBP C1) act not only on $\mathrm{NH}_{3}$-producing bacteria but also on protozoa.

Microbial protein synthesis and its efficiency were not affected by inclusion of propolis in the diet, similarly to what was observed in previous studies (Valero, 2010; Simioni, 2011; Aguiar et al., 2012). In dairy cows, allantoin and uric acid are secreted in the milk, and the amount secreted daily is equivalent to approximately $5 \%$ of the purine derivatives (PD) excreted in urine (Chen and Gomes, 1992). In our study, the corresponding value averaged $6.22 \%$. The efficiency of microbial synthesis was not affected $(\mathrm{P}>0.05)$ by inclusion of PBP in the diet. According to the NRC (1996), $130.0 \mathrm{~g} / \mathrm{kg}$ of TDN (microbial protein synthesis efficiency) is desirable, and only in the PBP C1 treatment was a comparable value attained.

The addition of the PBP did not affect any of the assayed blood parameters in the evaluated dairy cows. Similar results were reported by Faria et al. (2011), who found no effect of propolis (PBP C1 in two increasing doses) on blood urea concentrations in feedlot cattle. Similarly, Simioni (2011) reported no effect of propolis on blood parameters in feedlot cattle that were fed diets with higher propolis doses than those used by Faria et al. (2011).

The concentration of MUN has become a useful tool in predicting the efficiency of $\mathrm{N}$ use in dairy cows (Burgos et al., 2007). Dietary crude protein is the most 
important nutritional factor that influences the MUN, and its determination can be used as a diagnostic of protein feeding in dairy cows (Nousiainen et al., 2004) and for the identification and/or correction of deficiencies, excesses, or imbalances in dietary protein and energy (Godden et al., 2001). In the present study, the mean milk protein concentration and MUN were $3.69 \%$ and $14.63 \mathrm{mg} / \mathrm{dL}$, respectively. According to Godden et al. (2001), milk protein concentrations above $3.2 \%$ and MUN between 12 and $17 \mathrm{mg} / \mathrm{dL}$ indicate proper balance between the degradable protein and energy fermented in the rumen; the values obtained in our study are within these ranges.

For blood urea nitrogen (BUN), the obtained mean value was $18.72 \mathrm{mg} / \mathrm{dL}$. Oliveira et al. (2001) found that BUN values between 19 and $20 \mathrm{mg} / \mathrm{dL}$ and MUN values between 24 and $25 \mathrm{mg} / \mathrm{dL}$ represent thresholds that indicate the initiation of $\mathrm{N}$ losses. The values obtained for BUN and MUN in our study are below these thresholds.

\section{Conclusions}

The propolis-based products have positive effects on protein metabolism in the rumen, without interfering with any other parameter evaluated. The propolis concentration and alcoholic level used in this study influence the amounts of flavonoids and phenolic acids in the propolis-based products, which may interfere with the observed effects on ruminal metabolism and digestive parameters.

\section{References}

Aguiar, S. C.; Zeoula, L. M.; Franco, S. L.; Peres, L. P.; Arcuri, P. B. and Forano, E. 2013. Antimicrobial activity of Brazilian propolis extracts against rumen bacteria in vitro. World Journal of Microbiology and Biotechnology 29:1951-1959.

Aguiar, S. C.; Zeoula, L. M.; Moura, L. P. P.; Prado, I. N.; Paula, E. M. and Samensari, R. B. 2012. Performance, digestibility, microbial production and carcass characteristics of feedlot young bulls fed diets containing propolis. Acta Scientiarum: Animal Sciences 34:393-400.

AOAC - Association of Official Analytical Chemists. 1990. Official methods of analysis. 15th ed. AOAC International, Arlington, VA.

Bach, A.; Calsamiglia, S. and Stern, M. D. 2005. Nitrogen metabolism in the rumen. Journal of Dairy Science 88(E-Supl.):E9-E21.

Balcells, J.; Aris, A.; Serrano, A.; Seradj, A. R.; Crespo, J. and Devant, M. 2012. Effects of an extract of plant flavonoids (Bioflavex) on rumen fermentation and performance in heifers fed high-concentrate diets. Journal of Animal Science 90:4975-4984.

Bankova, V. 2005. Chemical diversity of propolis and the problem of standardization. Journal of Ethnopharmacology 100:114-117.

Bankova, V. 2009. Chemical diversity of propolis makes it a valuable source of new biologically active compounds. Journal of ApiProduct and ApiMedical Science 1:23-28.
Broudiscou, L. P.; Papon, Y. and Broudiscou, A. F. 2002. Effects of dry plant extracts on feed degradation and the production of rumen microbial biomass in a dual outflow fermenter. Animal Feed Science and Technology 101:183-189.

Burgos, S. A.; Fadel, J. G. and DePeters, E. J. 2007. Prediction of ammonia emission from dairy cattle manure based on milk urea nitrogen: relation of milk urea nitrogen to urine urea nitrogen excretion. Journal of Dairy Science 90:5499-5508.

Busquet, M.; Calsamiglia, S.; Ferret, A. and Kamel, C. 2006. Plant extracts affect in vitro rumen microbial fermentation. Journal of Dairy Science 89:761-771.

Calsamiglia, S.; Busquet, M.; Cardozo, P. W.; Castillejos, L. and Ferret, A. 2007. Invited review: Essential oils as modifiers of rumen microbial fermentation. Journal of Dairy Science 90:2580-2595.

Castro, M. L.; Cury, J. A.; Rosalen, P. L.; Alencar, S. M.; Ikegaki, M.; Duarte, S. and Koo, H. 2007. Própolis do sudeste e nordeste do Brasil: influência da sazonalidade na atividade antibacteriana e composição fenólica. Química Nova 30:1512-1516.

Chen, X. and Gomes, M. J. 1992. Estimation of microbial protein supply to sheep and cattle based on urinary excretion of purine derivatives: an overview of the technical details. Rowett Research Institute, Bucksburn. 21p. (Occasional publication).

Coelho da Silva, J. F. and Leão, M. I. 1979. Fundamentos de nutrição de ruminantes. Livroceres, Piracicaba.

Cottica, S. M.; Sawaya, A. C. H. F.; Eberlin, M. N.; Franco, S. L.; Zeoula, L. M. and Visentainer, J. V. 2011. Antioxidant activity and composition of propolis obtained by different methods of extraction. Journal of Brazilian Chemical Society 22:929-935.

Cushnie, T. P. T. and Lamb, A. J. 2011. Recent advances in understanding the antibacterial properties of flavonoids. International Journal of Antimicrobial Agents 38:99-107.

Dijkstra, J. 1994. Simulation of the dynamics of protozoa in the rumen. British Journal of Nutrition 72:679-699.

Estrada, G. O. D.; Mendes da Silva, J. F. and Antunes, O. A. C. 2008 Artepillin C: A review. Letters in Drug Design \& Discovery 5:88-92.

Eugene, M.; Archimede, H. and Sauvant, D. 2004. Quantitative metaanalysis on the effects of defaunation of the rumen on growth, intake and digestion in ruminants. Livestock Production Science 85:81-97.

Faria, L. A. N.; Barbosa, O. R.; Zeoula, L. M.; Aguiar, S. C.; Prado, R. M. and Bertolini, D. A. 2011. Produto à base de própolis (PBP) na dieta de bovinos inteiros confinados: comportamento animal e respostas sanguíneas. Acta Scientiarum: Animal Sciences 33:79-85.

Franco, S. L. and Bueno, J. H. F. 1999. Otimização de processo extrativo de própolis. Infarma 11:48-51.

Frozza, C. O. S.; Garcia, C. S. C.; Gambato, G.; de Souza M. D.; Salvador, M.; Moura, S.; Padilha, F. F.; Seixas, F. K.; Collares, T.; Borsuk, S.; Dellagostin, O. A.; Henriques, J. A. and Roesch-Ely, M. 2013. Chemical characterization, antioxidant and cytotoxic activities of Brazilian red propolis. Food and Chemical Toxicology 52:137-142.

Godden, S. M.; Lissemore, K. D. and Kelton, D. F. 2001. Relationships between milk urea concentrations and nutritional management, production, and economic variables in Ontario dairy herds. Journal of Dairy Science 84:1128-1139.

Leão, M. I.; Valadares Filho, S. C.; Rennó, L. N.; Cecon, P. R.; Azevedo, J. A. G.; Gonçalves, L. C. and Valadares, R. F. D. 2005. Consumos e digestibilidades totais e parciais de carboidratos totais, fibra em detergente neutro e carboidratos não-fibrosos em novilhos submetidos a três níveis de ingestão e duas metodologias de coleta de digestas abomasal e omasal. Revista Brasileira de Zootecnia 34:670-678.

Loureiro, C. M. B.; Sobrinho, A. G. S.; Santana, A. E.; Leão, A. G.; Perez, H. L. and Buzzulini, C. 2007. Eficácia do extrato de própolis 
no controle de helmintoses de cordeiros naturalmente infectados. In: Anais da $44^{\mathrm{a}}$ Reunião da Sociedade Brasileira de Zootecnia. Sociedade Brasileira de Zootecnia, Jaboticabal.

Lourenço, M.; Ramos-Morales, E. and Wallace, R. J. 2010. The role of microbes in rumen lipolysis and biohydrogenation and their manipulation. Animal 4:1008-1023.

NRC - National Research Council. 1996. Nutrient requirements of beef cattle. 7th ed. National Academy, Washington, DC.

NRC - National Research Council. 2001. Nutrient requirements of dairy cattle. 7th ed. National Academy of Science, Washington, DC.

Nousiainen, J.; Shingfield, K. J. and Huhtanen, P. 2004. Evaluation of milk urea nitrogen as a diagnostic of protein feeding. Journal of Dairy Science 87:386-398.

Oeztuerk, H.; Emre, B.; Sagmanligil, V.; Piskin, I.; Fidanci, U. R. and Pekcan, M. 2010. Effects of nisin and propolis on ruminal fermentation in vitro. Journal of Animal and Veterinary Advances 9:2752-2758.

Oliveira, A. S.; Valadares, R. F. D.; Valadares Filho, S. C.; Cecon, P. R.; Rennó, L. N.; Queiroz, A. C. and Chizzotti, M. L. 2001. Produção de proteína microbiana e estimativas das excreções de derivados de purinas e de uréia em vacas lactantes alimentadas com rações isoprotéicas contendo diferentes níveis de compostos nitrogenados não-protéicos. Revista Brasileira de Zootecnia 30:1621-1629.

Ozturk, H.; Pekcan, M.; Sireli, M. and Fidanci, U. R. 2010. Effects of propolis on in vitro rumen microbial fermentation. Ankara Üniversitesi Veteriner Fakültesi Dergisi 57:217-221.

Park, Y. K.; Alencar, S. M.; Scamparini, R. P. and Aguiar, C. L. 2002. Própolis produzida no sul do Brasil, Argentina e Uruguai: evidências fitoquímicas de sua origem vegetal. Ciência Rural 32:997-1003.

Prado, O. P. P.; Zeoula, L. M.; Moura, L. P. P.; Franco, S. L.; Prado, I. N. and Gomes, H. C. C. 2010. Digestibilidade e parâmetros ruminais de dietas à base de forragem com adição de própolis e monensina sódica para bovinos. Revista Brasileira de Zootecnia 39:1336-1345.

Ríspoli, T. B.; Rodrigues, I. L.; Martins Neto, R. G.; Kazama, R.; Prado, O. P. P.; Zeoula, L. M. and Arcuri, P. B. 2009. Protozoários ciliados do rúmen de bovinos e bubalinos alimentados com dietas suplementadas com monensina ou própolis. Pesquisa Agropecuária Brasileira 44:92-97.

Santos Neto, T. M.; Mota, R. A.; Silva, L. B. G.; Viana, D. A.; LimaFilho, J. L.; Sarubbo, L. A.; Converti, A. and Porto, A. L. F. 2009. Susceptibility of Staphylococcus spp. isolated from milk of goats with mastitis to antibiotics and green propolis extracts. Letters in Drug Design \& Discovery 6:63-68.

Simioni, F. L. 2011. Própolis como aditivo alimentar para bovinos de corte. Tese (D.Sc.). Universidade Estadual de Maringá, Maringá.

Sniffen, C. J.; O’Connor, J. D.; Van Soest, P. J.; Fox, D. G. and Russell, J. B. 1992. A net carbohydrate and protein system for evaluating cattle diets: II. Carbohydrate and protein availability. Journal of Animal Science 70:3562-3577.

Valero, M. V.2010. Monensina ou própolis na dieta de bovinos mestiços terminados em confinamento: desempenho, digestibilidade, produção microbiana, características da carcaça e do músculo Longissimus. Dissertação (M.Sc.). Universidade Estadual de Maringá, Maringá.

Van Soest, P. J.; Robertson, J. B. and Lewis, B. A. 1991. Methods for dietary fiber, neutral detergent fiber, and nonstarch polyssacharides in relation to animal nutrition. Journal of Dairy Science 74:3583-3597.

Van Soest, P. J. 1994. Nutritional ecology of the ruminant. 2nd ed. Cornell University Press, Ithaca.

Vieira, P. F. 1980. Efeito do formaldeído na proteção de proteínas e lipídeos em rações para ruminante. Tese (D.Sc.). Universidade Federal de Viçosa, Viçosa, MG, Brasil.

Wallace, R. J. 2004. Antimicrobial properties of plant secondary metabolites. Proceedings of the Nutrition Society 63:621-629.

Zawadzki, F.; Prado, I. N.; Marques, J. A.; Zeoula, L. M.; Rotta, P. P.; Sestari, B. B.; Valero, M. V. and Rivaroli, D. C. 2011. Sodium monensin or propolis extract in the diets of feedlot-finished bulls: effects on animal performance and carcass characteristics. Journal of Animal and Feed Sciences 20:16-25. 